\title{
Mineral prospectivity mapping with weights of evidence and fuzzy logic methods
}

\author{
Nannan Zhang ${ }^{\mathrm{a}, \mathrm{b}}$ and Kefa Zhou ${ }^{\mathrm{a}, \mathrm{b}, *}$ \\ ${ }^{a}$ Xinjiang Research Center for Mineral Resources, Xinjiang Institute of Ecology and Geography, \\ Chinese Academy of Sciences, Urumqi, Xinjiang, China \\ ${ }^{\mathrm{b}}$ Xinjiang Key Laboratory of Mineral Resources and Digital Geology, Urumqi, Xinjiang, China
}

\begin{abstract}
Knowledge-and data-driven approaches are two major methods used to integrate various evidential maps for mineral prospectivity mapping (MPM). Geological maps, geochemical samples and data from known gold deposits were collected in the western Junggar area, Xinjiang Province. The geological and a spatial database for geological and mineral occurrences were constructed for the studied region. A weights-of-evidence model and a fuzzy logic model were employed for MPM, and the results were compared. Results indicate that favorable sedimentary rocks, fault density, fault distance and concentration of Au were the primary factors affecting Au mineralization. Arsenic (AS), Stibium (Sb), fault direction, quartz veins and intrusive rocks were secondary factors affecting Au mineralization. Conditional independence exerted a major influence on the weights-of-evidence model. However, posterior probability would be very high if the conditional independence was disregarded, which impaired results. Combining the quantification results provided by weights-of-evidence and the fuzzy membership values determined by expert knowledge, the mineral prospectivity mapping according to the fuzzy logic method was proved to be valid. For the study area, which had a large number of deposits, data-driven approaches for MPM are generally considered to be appropriate. However, if sufficient data are not collected, the knowledge-driven approaches, for example, the fuzzy logic method used in the present study, usually achieves a better result.
\end{abstract}

Keywords: Mineral prospectivity mapping, weights-of-evidence, fuzzy logic

\section{Introduction}

Mineral exploration is a sophisticated process that seeks to discover new mineral deposits in a region of interest [28]. Mineral prospectivity mapping (MPM) is used as a tool to delineate target areas that most likely contain mineral deposits of a particular type [26]. In order to conduct MPM, multiple data sets, or layers (e.g., geological, geophysical, geochemical, and remote

\footnotetext{
${ }^{*}$ Corresponding author. Kefa Zhou, Xinjiang Research Center for Mineral Resources, Xinjiang Institute of Ecology and Geography, Chinese Academy of Sciences, Urumqi, Xinjiang 830011, China. Tel.: +86 1357987 7086; Fax: +86 991 7885320; E-mail: zhoukf@ms.xjb.ac.cn/znn_0802@163.com.
}

sensing data) must be collected, analyzed and integrated [17]. The integration of different digital geoscientific data sets is a key component of MPM. Typically, data integration is performed using geographic information system (GIS) applications.

Knowledge-and data-driven are two major types of approaches, which assign evidential weights and integrate various evidential maps for MPM and further exploration [10]. In data-driven techniques, the known mineral deposits in a region of interest are used as "training points" to recognize and establish spatial relationships of deposits with particular exploration evidential features [3], therefore, these techniques are proper in well-explored areas [3]. Examples of data- 
driven methods include weights-of-evidence [7], fuzzy weights-of-evidence [24], logistic regression [9], neural networks [27], Bayesian networks [4], and support vector machines [25]. In knowledge-driven techniques, few known mineral deposits are predicted in areas of interest, so expert experience and judgments are required. Analysts apply expert opinions to assess the relative importance of spatial evidence as meaningful decision support [19]. Several mineral potential mapping methods are classified as knowledge-driven techniques, including Boolean logic, index overlay, fuzzy analytical hierarchy process [3], and fuzzy logic [29].

In this study, after a brief introduction of the weightof-evidence and fuzzy logic methods, nine layers of geological and geochemical datasets are integrated for MPM. These two methods are tested in the Western Junnggar area of Xinjiang, China. The primary goal of this study was to compare the application effects of knowledge- and data-driven techniques for MPM when there were known mineral deposits, but a lack of other data about a given study area.

\section{Geological setting of the study area}

\subsection{Regional geological background}

The western Junggar area is located on the western margin of the Junggar Basin in the northern part of Xinjiang, China. In terms of administrative division, the western Junggar area belongs to Tacheng prefecture, Ili Kazakh Autonomous Prefecture. It extends to the Sawuer Mountain in the north, Ebinur Lake in the south, Buerkesidai-Karamay in the east, and OminTuoli-Alataw pass in the west (Fig. 1). The western Junggar area is the region known for the largest number of discovered gold deposits in Xinjiang, with over 200 gold deposits or mineralization occurrences. There is one proven large-scale gold deposit, two mediumscale gold deposits, five small-scale gold deposits, and over 190 mineralization occurrences [30].

The western Junggar area is situated at the convergence belt between the Siberian and Tarim Plates and in the Hercynian back-arc basin. Due to the influence of regional tectonic stress, the study area has relatively developed folds and fault structures. The strata cropped out in the western Junggar area primarily include Ordovician-Silurian epimetamorphic rock series in the lower Paleozoic, Devonian-Carboniferous marine volcanic rock-turbidite formations in the upper Paleozoic, and Permian-Triassic terrestrial volcano-molasses for-

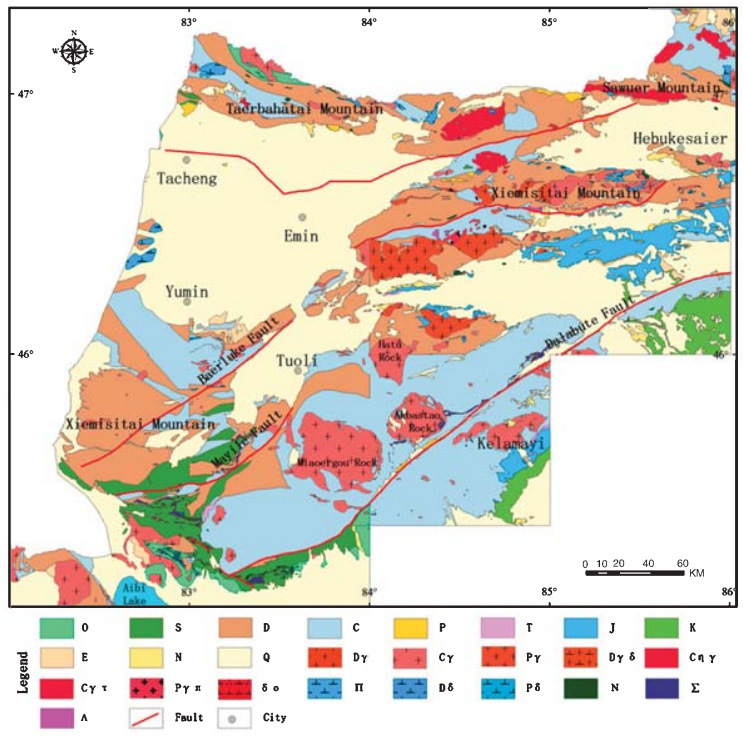

Fig. 1. Schematic map of geology in the western Junnggar, Xinjiang (modified based on 1:200,000 geological maps).

mations. Tailegula Formations, Baogutu Formations and Xibeikula Formations are the primary gold-bearing strata in the metallogenic districts; Devonian Kulumudi Formations are also a gold-bearing stratum. Neopaleozoic post-collisional plutonic rocks composed of intermediate-acid intrusive rocks are extensively developed in the metallogenic belt. They are divided into two categories. One is the huge acidic batholith dominated by alkali-feldspar granite, which is found on both sides of the Darabut fault and constitutes the Darabut alkali-rich igneous rock belt [31]. Examples falling into this category include the pluton under Miao'ergou, Akbastau, Karamay, and Hongshan. The other category consists of granodiorite-quartz diorite, which is primarly found in the form of small stock and distributed in the southeast of the Dalabut fault [5].

\subsection{Geological model}

The gold deposits in different parts of the western Junggar area form a group of deposits that are closely connected in terms of formation time, space and genesis. Deposited under a certain geological environment, they belong to the same metallogenic series and can be attributed to the metallogenic events in the upper and middle Variscan [13]. Thus, a conceptual model for gold deposit formation in the western Junggar area was proposed, as shown in Table 1. 
Table 1

The geological model of gold deposits in western Junggar

\begin{tabular}{|c|c|c|}
\hline \multicolumn{2}{|c|}{ Metallogenic factor } & \multirow{2}{*}{$\begin{array}{l}\text { Contents of description } \\
\text { The NE-trending regional deep fault is the most important rock-controlling } \\
\text { structure in this region. The position where the EW-trending deep fault } \\
\text { converges with the NE-trending deep fault is usually the favorable } \\
\text { metallogenic belt. }\end{array}$} \\
\hline \multirow[t]{5}{*}{$\begin{array}{l}\text { Geological } \\
\text { tectonic } \\
\text { background }\end{array}$} & Tectonic environment & \\
\hline & Intrusive rocks & $\begin{array}{l}\text { The intrusion of intermediate-acid magma is closely associated with the } \\
\text { formation of gold deposits. As the major metallogenic factor in this region, } \\
\text { intermediate-acid intrusive rock has a special spatial relationship with ore } \\
\text { deposits. }\end{array}$ \\
\hline & Ore-bearing strata & $\begin{array}{l}\text { Most of the gold deposits and gold occurrences in this region are concentrated } \\
\text { in the middle-upper Carboniferous Tongbaogutu Formation and Tailegula } \\
\text { Formation of the Paleozoic era. Lithologically, they are tuffaceous siltstone, } \\
\text { siliceous tuff, and basalt. }\end{array}$ \\
\hline & Wallrock alteration & $\begin{array}{l}\text { Common forms of wallrock alteration include pyritization, arsenopyritization, } \\
\text { carbonatization, siliconization and sericitization. }\end{array}$ \\
\hline & Markers of gold-bearing dykes & $\begin{array}{l}\text { Quartz veins are widely distributed in this region, especially in siliceous rocks. } \\
\text { Gold deposits with industrial significance can be seen in some places. }\end{array}$ \\
\hline $\begin{array}{l}\text { Regional } \\
\text { geophysical field }\end{array}$ & Gravity & $\begin{array}{l}\text { The gravity field in the gold deposit is elliptical, distribute in EW-NE } \\
\text { direction. The contours near the faults are obviously twisted or linear. }\end{array}$ \\
\hline Regional geochemical fiel & & $\begin{array}{l}\mathrm{Au}, \mathrm{As} \text {, and Sb elements are evenly distributed in each metallogenic sub-belt } \\
\text { of the western Junggar area. Geochemical anomalies are common for } \mathrm{Au}, \\
\mathrm{As} \text {, and Sb elements, with a narrow strip-like distribution pattern. As and } \mathrm{Sb} \\
\text { anomalies indicate anomalous mineralization. }\end{array}$ \\
\hline
\end{tabular}

\section{Methodology}

\subsection{Weights-of- evidence}

Weights-of-evidence (W-of-E) is a data driven method for mineral potential mapping (MPM). It was first applied to the prediction of mineral deposits by Bon-ham-Carter et al. [11]. This data-driven method can estimate the relative importance of individual layers of evidence by statistical means, and requires a min eral deposit dataset and a series of geological features in order to generate a mineral potential map [26]. The weights-of-evidence modeling technique comprises five steps:

- The estimation of prior probability $\mathrm{P}\{\mathrm{D}\}$, the probability that a mineral occurrence exists in an area given no additional information. $\mathrm{P}\{\mathrm{D}\}=\mathrm{N}\{\mathrm{D}\} / \mathrm{N}\{\mathrm{T}\}$, where $\mathrm{N}\{\mathrm{D}\}$ is the number of units covering the occurrence points and $\mathrm{N}\{\mathrm{T}\}$ is the number of all units in the study area;

- Determination of weighting coefficients $\left(W^{+}\right.$, $\left.W^{-}\right)$, contrast $(C)$, and studentized contrast $(S(C))$, expressed as follows:

$$
\begin{gathered}
W^{+}=\ln \frac{P\{B \mid D\}}{P\{B \mid \bar{D}\}} ; W^{-}=\ln \frac{P\{\bar{B} \mid D\}}{P\{\bar{B} \mid \bar{D}\}} \\
C=W^{+}-W^{-}
\end{gathered}
$$

\section{Studentized (Contrast)}

$$
=S^{2}(C) / \sqrt{S^{2}\left(W^{+}\right)+S^{2}\left(W^{-}\right)}
$$

- Calculation of posterior probability $P(D / B)$, the probability of an occurrence in an area given weights and additional information, as follows:

$$
\begin{aligned}
& P\left(D \mid B_{1} \cap B_{2} \cap \ldots \cap B_{\ldots} \cap B_{n}\right) \\
& \quad=P(D) \frac{P\left(B_{1} \mid D\right)}{P\left(B_{1}\right)} \frac{P\left(B_{2} \mid D\right)}{P\left(B_{2}\right)} \ldots \frac{P\left(B_{\ldots} \mid D\right)}{P\left(B_{\ldots}\right)} \frac{P\left(B_{n} \mid D\right)}{P\left(B_{n}\right)}
\end{aligned}
$$

- Testing for conditional independence;

- Validation [18].

The difference between the two weights is known as the weights contrast (C). A contrast reflects the overall spatial association between the evidential layer and the mineral deposits. Studentized contrast represetns the ratio of contrast and the contrast standard deviation. This value reflects the significance level of the $C$ value. In the present study, the influence of each weights-ofevidence layer of mineral deposits was quantitatively measured by $\mathrm{C}$ and $\mathrm{S}(\mathrm{C})$. One of the common criticisms of the weights-of-evidence method for mineral potential mapping is the problem of conditional independence [8]. In the weights-of-evidence model, one important assumption is that all evidential layers of the model 
are conditionally independent of mineralization; otherwise, this will lead to posterior probability departure and unreliability of predictions. To satisfy the conditional independence assumption, the data that may be problematic were eliminated from this paper.

\subsection{Fuzzy logic}

Fuzzy logic is based on the fuzzy-set theory proposed by Zadeh [14], and allows the geologist to utilize their knowledge to build models used to generate mineral potential maps, and select the evidential layers that they believe are most critical for the particular style of mineralization. Additionally, fuzzy logic allows weights to be assigned to each layer based on expert opinion [16]. The Boolean set theory defines a membership which is either 1 or 0 (true or false), whereas the fuzzy-set theory defines a degree of membership in a set, represented by a value between 0 and 1 without a crisp boundary [1].

The fuzzy model for mineral prediction is defined as a generic model: if $X$ represents the set of evidential layers $X_{i}(i=1,2,3, \ldots, n)$ and the layer has $r$ classes defined as $(j=1,2,3, \ldots, r)$, then $\mathrm{n}$ fuzzy sets $A_{i}(i=1,2,3, \ldots, n)$ in $X$ are defined by Equation (5), as follows:

$$
A_{i j}=\left\{\left(x_{i j}, \mu A\right) / x i j \in X i\right\},(0 \leq \mu A \leq 1)
$$

where $\mu_{A}$ is the membership value. When $x_{i j}$ is favorable to mineralization, $0.5<\mu_{A}<1$; when and only when it cannot be determined whether $x_{i j}$ is favorable or unfavorable to mineralization, $\mu_{A}=0.5$; when $x_{i j}$ is unfavorable to mineralization, $0<\mu_{A}<0.5$. The value of the membership function can be determined by two methods. One method is to calculate according to the membership function curve; the other is to assign values artificially according to geological knowledge, i.e., a membership function is constructed using a $t[0]$ abulation method. The membership functions have a variety of forms, typically: Gaussian, triangular, trapezoidal and sigmoidal [20]. A sigmoidal membership function is adopted in the present work. The function is expressed in Equation (6):

$$
\mu_{A_{x j}}=\frac{1}{1+e^{-a\left(x_{i j}-b\right)}}
$$

where $x_{i j}$ is the $j$-th class of the $i$-th layer, $x_{i j}=w_{i} \times$ $w_{j} ; w_{i}$ is the weight of the $i$-th evidential layer, and $w_{j}$ the weight of the $j$-th class of the evidential layer. In this equation, $a$ and $b$ determine the shape of the function. Here the value of $a$ is 0.1 and the value of $b$ is 50 .
Using a fuzzy set operator, $\mathrm{n}$ fuzzy sets Ai are integrated to form a comprehensive fuzzy set F, expressed by Equation (7):

$$
F=\sum_{i=1}^{n} \mathrm{~A}_{\mathrm{i}}
$$

where $\Sigma$ is the operation of the fuzzy set. A comprehensive fuzzy set is the fuzzy set comprising the favorable exploration target.

The fuzzy model in mineral prediction consists of two steps: (1) fuzzification of data; (2) fuzzy synthesis of fuzzified data. Fuzzification can be realized by determining the fuzzy function. Fuzzy synthesis is executed by using the operator. The most basic fuzzy operators are: (1) fuzzy AND; (2) fuzzy OR; (3) fuzzy algebraic product; (4) fuzzy algebraic sum; and (5) fuzzy gamma [23]. Note that $\mu(x)$ represents the fuzzy membership value. The fuzzy AND and fuzzy algebraic sum operators were not used to calculate Au deposit prospectivity in the current study.

\subsubsection{Fuzzy OR}

$$
u_{(x)}=\operatorname{Max}\left(\mu_{A}, \mu_{B}, \mu_{C} \ldots\right)
$$

Fuzzy OR values are the maximum membership values from each evidential layer. Thus, fuzziness or the membership value of each grid unit is controlled by the maximum membership value in each grid.

\subsubsection{Fuzzy algebraic product}

$$
u_{(x)}=\coprod_{i=1}^{n} u_{i}
$$

Membership values from each evidential layer at each location are multiplied to calculate the fuzzy algebraic product. Thus, the fuzzy membership value of each evidential layer has an influence on the calculation result.

\subsubsection{Fuzzy gamma}

$$
\mu_{(x)}=\left[\coprod_{i=1}^{n} u_{i}\right]^{\gamma} \cdot\left[1-\coprod_{i=1}^{n}\left(1-u_{i}\right)\right]^{1-\gamma}
$$

The gamma operator achieves a synthesis result within the interval between the maximum and the minimum membership value. This value range is affected by the fuzzy membership value of the input evidence 


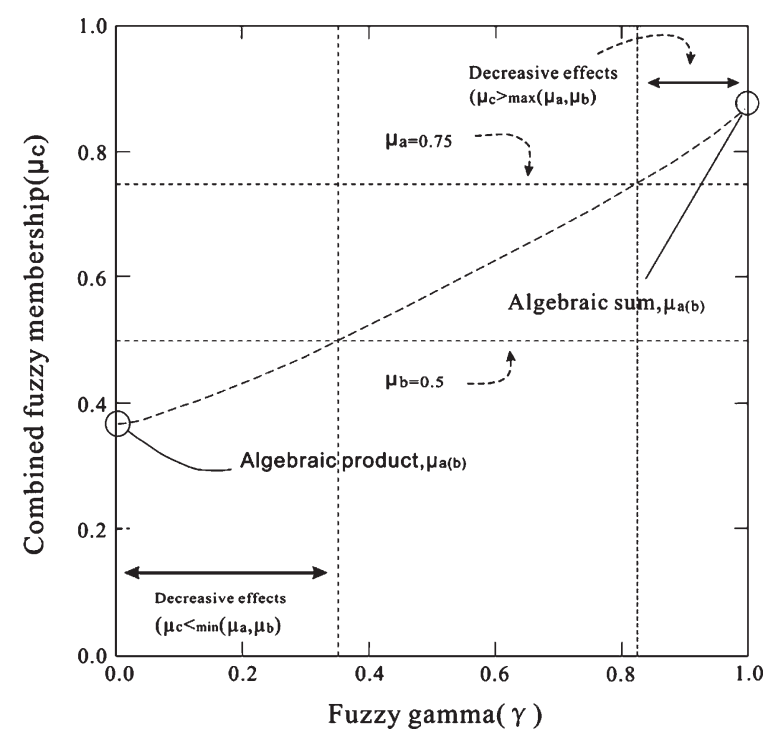

Fig. 2. The effect of fuzzy gamma values $(\gamma)$ on combining fuzzy memberships $\mu_{a}$ and $\mu_{b}$ to determine combined fuzzy membership $\mu_{c}[18]$.

(Fig. 2). The value of $\gamma$ is within the interval of $0-1$; when $\gamma=1$, the result of fuzzy synthesis is equal to the fuzzy algebraic sum (0.88 in Fig. 2); when $\gamma=0$, the result of fuzzy synthesis is equal to the fuzzy algebraic product ( 0.38 in Fig. 2). If $0<\gamma<0.35$, then $\mu_{c}$ is less than the smaller input membership value $(0.5)$. If $0.8<\gamma<1$, then $\mu_{c}$ is higher than the higher input value (0.75). The limits 0.35 and 0.8 are specific to the input values $\mu_{a}$ and $\mu_{b}$ respectively [18].

\section{Datasets}

In this study, geological and geochemical datasets were used as sources of evidence for mineral prospectivity mapping. The 13 geological maps were received from the Xinjiang Bureau of Geology and Mineral Resources, obtained by field surveys and mapping at a scale of $1: 200,000$. The geochemical data comprised of 39 major and trace elements within 8104 samples. A spatial database was developed to manage the geological and geochemical data in ArcGIS10.1. A geographic coordinate system, namely, Beijing 1954, was used (6degree Gauss-Kruger zone 14 , central meridian $81^{\circ}$, and unit $\mathrm{m}$ ). The database comprises planar, linear and point features: (1) point features representing the Au mineral deposits; (2) linear features representing faults, geological boundaries and attitudes; (3) planar features representing intrusive rocks, sedimentary (volcanic) strata and quartz veins.

\section{Application of mineral prospectivity mapping techniques}

\subsection{Weights of evidence (W-of-E)}

In this study, according to the expert opinions, geological model and the collected data, nine data layers are used for MPM, including fault density, fault distance, fault direction, intrusive rocks, quartz veins, sedimentary rocks and concentrations of $\mathrm{Au}, \mathrm{As}$ and $\mathrm{Sb}$. The study area is $50356 \mathrm{~km}^{2}$ in size, divided into units with areas of $0.25 \mathrm{~km}^{2}$. The number of gold deposits (including mineralization occurrences) is 240, with prior probability of 0.001192 .

\subsubsection{Spatial analysis}

The associations between these nine types of data and gold deposits (mineralization occurrences) are analyzed quantitatively (Table 2). A StudC value greater than 1.5 infers a true, strong positive correlation and a StudC value greater than 0.5 but less than 1.5 infers a true but weak positive correlation [21]. Therefore the weightsof-evidence layer with $\mathrm{S}(\mathrm{C})$ above 1.0 is considered to demonstrate close association with gold deposits. Analysis is conducted according to the following procedures:

- Spatial analysis of faults data:

Faults play a role in enabling fluid passage during mineralization [26]. The objective of fault density analysis is to determine the distribution of faults over the entire region, and the degree of fault convergence. On this basis, the spatial association between fault convergence and the known deposits can be analyzed. The results are shown in Fig. 3, and indicate that the faults are more concentrated in the middle and northwest regions of the study area; the area with high-value fault density in the middle corresponds to the locations of known deposits. As shown in Table 2, fault density has a controlling effect on gold deposits. That is, over the interval of fault density of $0.572-1.288$ from the 5th class to the 9th class, the $\mathrm{S}(\mathrm{C})$ reaches a maximum of 14.7403 , indicating extremely large influence on mineralization. For fault distance analysis, Euclidean distance is used to measure the shortest distance from the pixel to the center of the designated target. By this means, the spatial association between the distance of fault and deposits is determined. The maximum fault distance is $5000 \mathrm{~m}$, as shown in Fig. 3 . When the fault distance is $0.0-0.5 \mathrm{~km}$, the $S(C)$ is 9.4142. Fault direction analysis represents the direction 
Table 2

Quantitative evaluation of spatial relationship between gold deposits and nine evidential layers $(\mathrm{S}(\mathrm{C})>1.0)$

\begin{tabular}{|c|c|c|c|c|c|}
\hline Evidential Layers & Class & Area $\left(\mathrm{km}^{2}\right)$ & Points & $\mathrm{C}$ & $\mathrm{S}(\mathrm{C})$ \\
\hline Fault density & $0.572-0.715$ & 4738.875 & 55 & 1.051 & 6.835 \\
\hline Fault density & $0.715-0.859$ & 3111.688 & 48 & 1.335 & 8.256 \\
\hline Fault density & $0.859-1.002$ & 1734.063 & 31 & 1.427 & 7.397 \\
\hline Fault density & $1.002-1.145$ & 500.438 & 23 & 2.365 & 10.730 \\
\hline Fault density & $1.145-1.288$ & 123.750 & 19 & 3.588 & 14.740 \\
\hline Fault distance (m) & $0-500$ & 13967.063 & 158 & 1.282 & 9.414 \\
\hline Fault direction & $-1^{\circ}-22.5^{\circ}$ & 5169.250 & 52 & 0.625 & 3.984 \\
\hline Fault direction & $337.5^{\circ}-360^{\circ}$ & 7413.938 & 56 & 0.293 & 1.917 \\
\hline intrusive rocks buffer (m) & $5000-6000$ & 3178.875 & 21 & 0.234 & 1.003 \\
\hline quartz veins buffer (m) & $0-500$ & 1580.000 & 39 & 0.569 & 2.965 \\
\hline Sedimentary rocks & $\mathrm{D}_{2}^{\mathrm{d}}$ & 96.813 & 43 & 4.792 & 26.984 \\
\hline Sedimentary rocks & $\mathrm{C}_{2-3} \mathrm{~b}^{\mathrm{a}}$ & 11.625 & 5 & 4.572 & 9.563 \\
\hline Sedimentary rocks & $\mathrm{C}_{2-3} \mathrm{~b}^{\mathrm{b}}$ & 80.125 & 17 & 3.860 & 14.929 \\
\hline Sedimentary rocks & $\mathrm{C}_{2-3} \mathrm{t}$ & 55.688 & 11 & 3.757 & 11.867 \\
\hline Sedimentary rocks & $\mathrm{D}_{2} \mathrm{c}$ & 88.938 & 13 & 3.451 & 11.873 \\
\hline Sedimentary rocks & $\mathrm{C}_{2-3} \mathrm{t}^{\mathrm{b}}$ & 170.625 & 9 & 2.388 & 6.976 \\
\hline Sedimentary rocks & $\mathrm{C}_{2} \mathrm{~m}$ & 339.438 & 10 & 1.800 & 5.547 \\
\hline Sedimentary rocks & $\mathrm{C}_{2} \mathrm{x}$ & 1665.938 & 37 & 1.617 & 8.986 \\
\hline Sedimentary rocks & $\mathrm{C}_{1} \mathrm{t}$ & 1938.375 & 22 & 0.862 & 3.837 \\
\hline Sedimentary rocks & $\mathrm{C}_{1} \mathrm{~b}$ & 2704.125 & 30 & 0.860 & 4.386 \\
\hline $\mathrm{Au}(\mathrm{ppb})$ & $1.8-2.1$ & 1896.625 & 21 & 0.618 & 2.700 \\
\hline $\mathrm{Au}(\mathrm{ppb})$ & $2.1-2.7$ & 2298.688 & 22 & 0.465 & 2.077 \\
\hline $\mathrm{Au}(\mathrm{ppb})$ & $2.7-3.3$ & 1111.188 & 19 & 1.066 & 4.449 \\
\hline $\mathrm{Au}(\mathrm{ppb})$ & $3.3-3.9$ & 667.250 & 24 & 1.849 & 8.558 \\
\hline $\mathrm{Au}(\mathrm{ppb})$ & $3.9-4.5$ & 400.938 & 29 & 2.587 & 12.958 \\
\hline $\mathrm{Au}(\mathrm{ppb})$ & $4.5-5.1$ & 292.500 & 19 & 2.434 & 10.105 \\
\hline $\mathrm{Au}(\mathrm{ppb})$ & $5.1-5.7$ & 174.750 & 19 & 2.964 & 12.240 \\
\hline $\mathrm{Au}(\mathrm{ppb})$ & $5.7-6.3$ & 66.375 & 2 & 1.589 & 2.230 \\
\hline $\mathrm{Au}(\mathrm{ppb})$ & $6.3-6.7$ & 13.313 & 2 & 3.228 & 4.460 \\
\hline As (ppm) & $12-16$ & 10076.313 & 77 & 0.290 & 2.093 \\
\hline As (ppm) & $16-20$ & 5049.750 & 40 & 0.284 & 1.636 \\
\hline As (ppm) & $20-24$ & 2751.625 & 26 & 0.459 & 2.207 \\
\hline As (ppm) & $24-28$ & 1419.000 & 16 & 0.627 & 2.420 \\
\hline $\mathrm{Sb}(\mathrm{ppm})$ & $0.6-0.8$ & 11139.563 & 98 & 0.529 & 4.027 \\
\hline $\mathrm{Sb}(\mathrm{ppm})$ & $0.8-1.0$ & 7257.313 & 55 & 0.248 & 1.612 \\
\hline
\end{tabular}

of a certain pixel with respect to the nearest fault line in numerical form, reflecting the spatial distribution characteristics of faults. Nine directions of faults are considered: north $\left(-1^{\circ}-22.5^{\circ}\right)$, northeast $\left(22.5^{\circ}-67.5^{\circ}\right)$, east $\left(67.5^{\circ}-112.5^{\circ}\right)$, southeast $\left(112.5^{\circ}-157.5^{\circ}\right)$, south $\left(157.5^{\circ}-202.5^{\circ}\right)$, southwest $\left(202.5^{\circ}-247.5^{\circ}\right)$, west $\left(247.5^{\circ}-292.5^{\circ}\right)$, northwest $\left(292.5^{\circ}-337.5^{\circ}\right)$, and north $\left(337.5^{\circ}-360^{\circ}\right)$. Ss shown in Fig. 3, results indicate that most faults are northeast- and southeast-trending. As shown in Table 2, the influence of fault direction on gold deposits or mineralization occurrences is primarily manifested in the first $\left(-1^{\circ}-22.5^{\circ}\right)$ and the ninth $\left(337.5^{\circ}-360^{\circ}\right)$ directions, with $\mathrm{S}(\mathrm{C})$ reaching a maximum of 3.9844. Therefore, fault density, fault distance, and fault direction are considered to be factors which influence the quantitative evaluation of favorability for gold mineralization.
- Spatial analysis of intrusive rocks

Granite is most-extensively distributed in the study area, followed by ultramaficrock, diorite and inter mediate-acid dyke, which are dated to the middlelate Hercynian. One intermediate-felsicacid magmatic event occurred in the Hercynian belt. As a result, multistage intrusive rocks of varying scale were formed. With the exception of ultramafic rocks, the gold content is higher in intermediate-basic rocks.

Magmatic activities play a crucial role in gold enrichment [2]. Therefore, intrusive rocks are selected from the database for buffer analysis. The maximum influence range of intrusive rocks is $8 \mathrm{~km}$, as shown in Fig. 3 .

Intrusive rocks have a smaller controlling effect on gold deposits, which is primarily manifested in the $6^{\text {th }}$ class (Table 2). That is, when the distance from rocks 

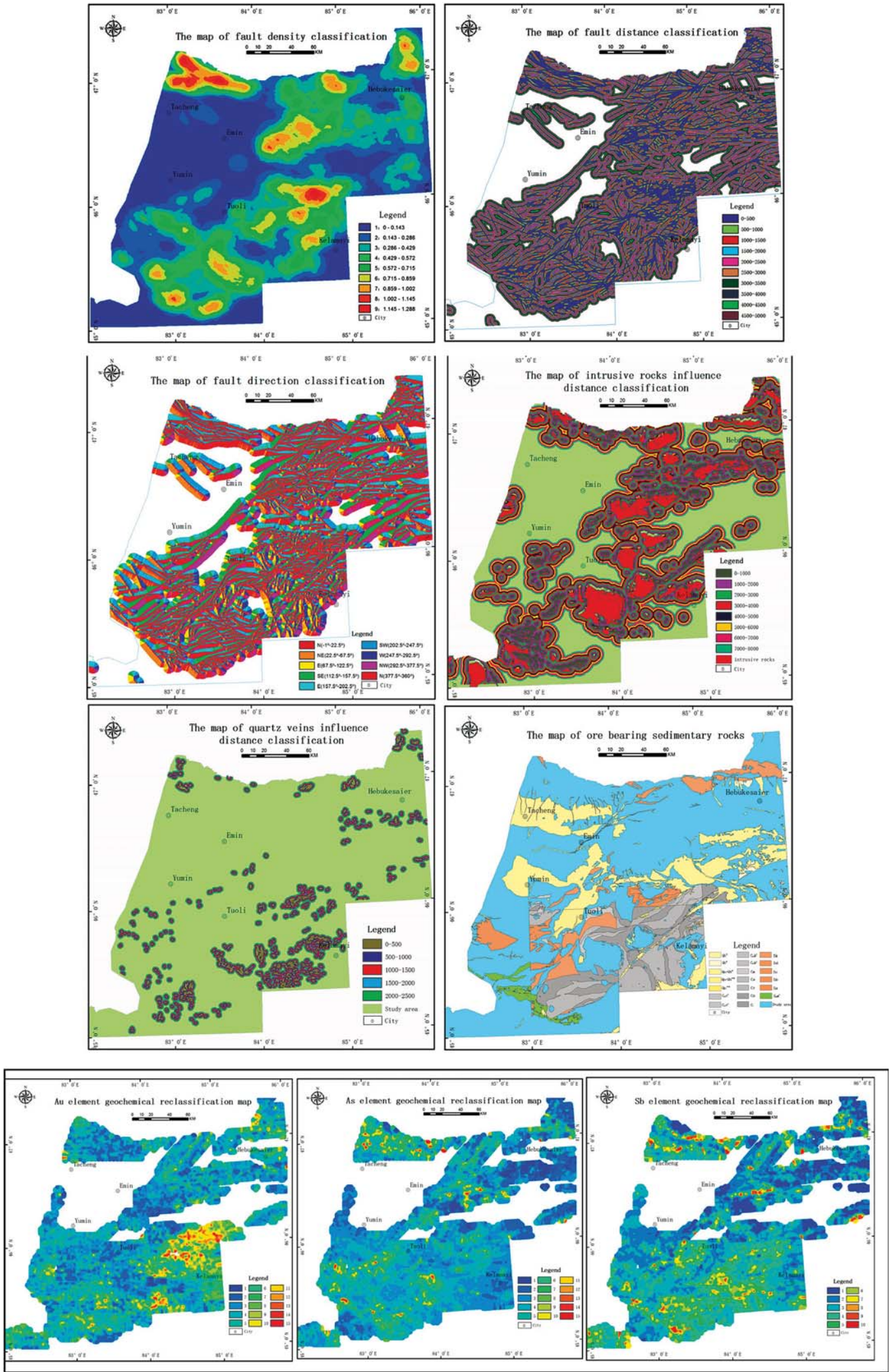

Fig. 3. Spatial analysis map of nine layers. 
is $5.0-6.0 \mathrm{~km}$, the $\mathrm{S}(\mathrm{C})$ is only 1.0031 . In terms of data-driven approaches, intrusive rocks have a smaller influence on mineralization. As indicated by the mineralization conceptual model, intrusive rocks, especially small intrusions, are more closely associated with gold deposits. Therefore, an intrusive rock buffer distance of $5.0-6.0 \mathrm{~km}$ is considered as an influence factor that is favorable for gold mineralization.

- Spatial analysis of quartz veins

The mineralization conceptual model indicates that gold deposits are closely related to quartz veins. Generally, quartz veins can be found at the sites of gold deposits. Therefore, buffer analysis and reclassification are performed for quartz veins. Combinedwith expert knowledge, the maximum influence range of quartz veins is determined to be $2.5 \mathrm{~km}$, as shown in Fig. 3 . Calculation results are shown in Table 2; results indicate that the $\mathrm{S}(\mathrm{C})$ within $0-500 \mathrm{~m}$ is 2.9646 . Thus, the occurrence of quartz veins within this distance is an influence factor that is favorable for gold mineralization in the quantitative evaluation.

- Spatial analysis of sedimentary rocks

The study area is comprised of a great variety of sedimentary rocks, totaling 154 types. According to spatial overlay superimposition on the known deposits, 230 deposits are located in the sedimentary formations, accounting for $95.8 \%$. As shown in Table 2, sedimentary rocks have a controlling effect on gold deposits. The maximum $\mathrm{S}(\mathrm{C})$ reaches 26.9836 , indicating the extremely large influence of sedimentary rocks on mineralization. Therefore, the discovery of these sedimentary rocks can be considered an influence factor of favorability for gold mineralization.

- Spatial analysis of geochemical data

Geochemical anomalies are not controlling factors, but are responses of specific mineralization processes
[26]. $\mathrm{Au}, \mathrm{As}$ and $\mathrm{Sb}$ results indicate that close relationships to the formation of gold deposits are subject to rasterization on the basis of Kriging interpolation. Reclassification maps of the three elements are obtained (Fig. 3). It is determined by reclassification and superimposition spatial overlay analysis that most deposits fall within the high peak area of Au content, and some within the high peak areas of As and Sb contents. As shown in Table 2, the $\mathrm{S}(\mathrm{C})$ of Au content increases from 1.8 , and the increase becomes more rapid after 2.7 until reaching the maximum of 4.4602 at $6.3-6.7 \mathrm{ppb}$. This indicates that $\mathrm{Au}$ content has an extremely large influence on mineralization. When As content is $12-28 \mathrm{ppm}$, the $\mathrm{S}(\mathrm{C})$ is 2.4197 ; when the $\mathrm{Sb}$ content is $0.6-1.0 \mathrm{ppm}$, the studentized contrast is 4.0265. Therefore, Au, As and $\mathrm{Sb}$ contents within these intervals are influence factors of favorability for gold mineralization.

\subsubsection{CI test and calculation of posterior probability}

Conducting the W-of-E modeling requires evidence map patterns to satisfy the pairwise conditional independence (CI) assumption [28]. An $\chi^{2}$ (chi-square) test was used to verify whether the weights-of-evidence layers satisfied the conditional independence assumption. The results of the $\chi^{2}$ test are shown in Table 3 . The criterion is that $\chi^{2}$ is 6.635 under the degree of freedom of 1 and a significance level of 0.01 . Thus, the $\chi^{2}$ value is larger than 6.635 and the probability value is smaller than 0.01 , indicating failure to meet the conditional independence assumption. As shown in Table 3, fault density, intrusive rocks, fault distance, As, and Au cannot be placed in the weights-of-evidence model simultaneously. Therefore, the four weights-ofevidence layers are removed. As a result, only five weights-of-evidence layers are left, namely Au content, $\mathrm{Sb}$ content, sedimentary rocks, fault distance and quartz veins. By introducing these five weights-ofevidence layers into the weights-of-evidence model,

Table 3

The table of value of $\chi^{2}$

\begin{tabular}{|c|c|c|c|c|c|c|c|c|}
\hline Evidential Layers & Sb content & Intrusive rocks & Fault distance & As content & Au content & Sedimentary rocks & Fault direction & Fault density \\
\hline Quartz veins & 2.06 & 0.76 & 0.19 & 9.25 & 4.39 & 0.90 & 1.07 & 1.19 \\
\hline Sb content & & 0.09 & 0.01 & 2.79 & 5.72 & 0.04 & 0.07 & 2.43 \\
\hline Intrusive rocks & & & 0.92 & 8.72 & 7.48 & 0.19 & 4.10 & 7.31 \\
\hline Fault distance & & & & 0.02 & 1.93 & 0.09 & 19.48 & 18.69 \\
\hline As content & & & & & 3.78 & 7.75 & 0.01 & 13.98 \\
\hline Au content & & & & & & 0.18 & 0.98 & 35.62 \\
\hline Sedimentary rocks & & & & & & & 0.09 & 0.10 \\
\hline Fault direction & & & & & & & & 0.80 \\
\hline
\end{tabular}


the posterior probability of mineralization in the study area is calculated. The relationship between the posterior probability of mineralization and the cumulative area is shown in Fig. 4. Based on posterior probability, the study area is divided into three categories: non-metallogenic districts, medium-favorability metallogenic districts, and high-favorability metallogenic districts. A mineral prospectivity map of the study area was obtained based on the weights-of-evidence model (Fig. 5).

\subsection{Fuzzy logic}

The fuzzy logic method is essentially knowledgedriven. Here, value is assigned to metallogenic data

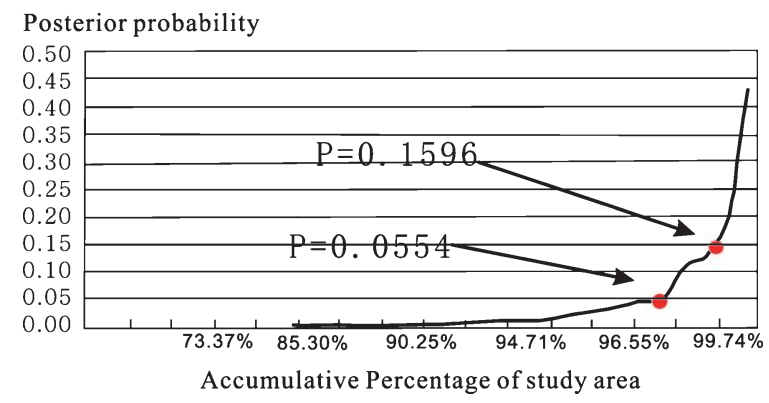

Fig. 4. The cumulative relationship between posterior probability and study areas.

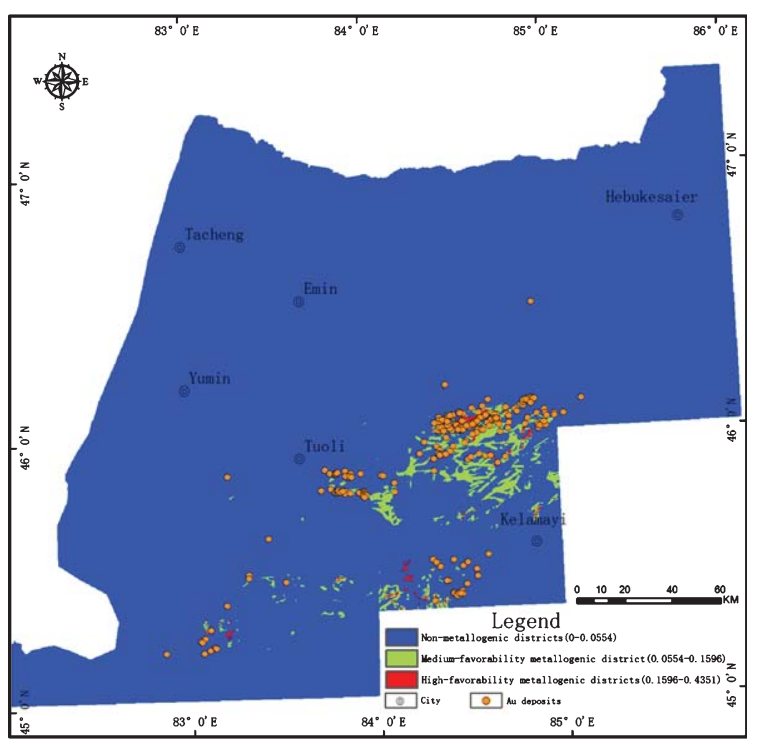

Fig. 5. Mineral prospectivity mapping with W-of-E (having passed conditional independence test). sets by combining quantificational weights-of-evidence calculations and expert knowledge. A value of 10 is assigned to metallogenic data sets of sedimentary rocks; a value of 9 is assigned to geochemical anomaly of $\mathrm{Au}$; a value of $e$ is assigned to metallogenic data sets of faults; a value of 8 is assigned to the metallogenic data sets of quartz veins; a value of 7 is assigned to intrusive rocks; and a value of 7 is assigned to the geochemical anomaly of As and Sb. Thus, the membership value of metallogenic data sets in the study area is calculated, with the fuzzy membership values of faults shown in Table 4. The membership value of other layers is calculated identically. Next, fuzzy synthesis is performed for all evidential layers according to four schemes, respectively (Fig. 6). As shown in Table 5, results indicate that scheme $\mathrm{D}$ is finally selected for subsequent prediction. A mineral prospectivity map based on fuzzy logic model is drawn, as shown in Fig. 7.

\section{Validation}

Generally, the discovery of new deposits is the best validation of metallogenic prediction. However, such validation can hardly be achieved in a study region as extensive as the western Junggar area, which usually requires a large investment in time and capital. Kemp presented two methods of validation [15]: (1) test whether the metallogenic districts have a higher probability; and (2) compare with the results from other methods. Bonham-Carter also proposed that an ore-forming potential map can be used to predict the deposit distribution and hence to validate the established model [12]. In this paper, the first method was used for validation. As shown in Table 6, the fuzzy logic mineral prospectivity map predicts $75 \%$ highand medium-favorability metallogenic districts of the known deposits within $14 \%$ of the study area.; the posterior probability reaches 0.9739 and only $25 \%$ of the deposits are outside the predicted districts. As shown from the predictions in Fig. 7, most deposits are distributed in the prediction regions; only a few known deposits are outside the prediction regions, demonstrating a scattered distribution pattern. This may be due to the lack of some metallogenic information (e.g., gravity data) for this district. Based on the above evaluation, it is concluded that the fuzzy logic method can be applied to the mapping of potential metallogenic districts with high accuracy. 
Table 4

Fuzzy membership value of faults

\begin{tabular}{lccccc}
\hline $\begin{array}{l}\text { Fault } \\
\text { distance }(\mathrm{m})\end{array}$ & $\begin{array}{c}\text { Fault } \\
\text { distance }(\mathrm{m})\end{array}$ & $\begin{array}{c}\text { Weight of } \\
\text { layer }\end{array}$ & $\begin{array}{c}\text { Weight of } \\
\text { class }\end{array}$ & $\begin{array}{c}\text { Score of } \\
\text { class }\end{array}$ & $\begin{array}{c}\text { Fuzzy membership } \\
\text { value }\end{array}$ \\
\hline & $0-500$ & 8 & 10 & 80 & 0.952574 \\
$500-1000$ & 8 & 6 & 48 & 0.450166 \\
$1000-1500$ & 8 & 5 & 40 & 0.268941 \\
$1500-2000$ & 8 & 3 & 24 & 0.069138 \\
$2000-2500$ & 8 & 4 & 32 & 0.141851 \\
$2500-3000$ & 8 & 6 & 48 & 0.450166 \\
$3000-3500$ & 8 & 2 & 16 & 0.032295 \\
$3500-4000$ & 8 & 6 & 48 & 0.450166 \\
$4000-4500$ & 8 & 1 & 8 & 0.014774 \\
$4500-5000$ & 8 & 6 & 48 & 0.450166 \\
\hline
\end{tabular}

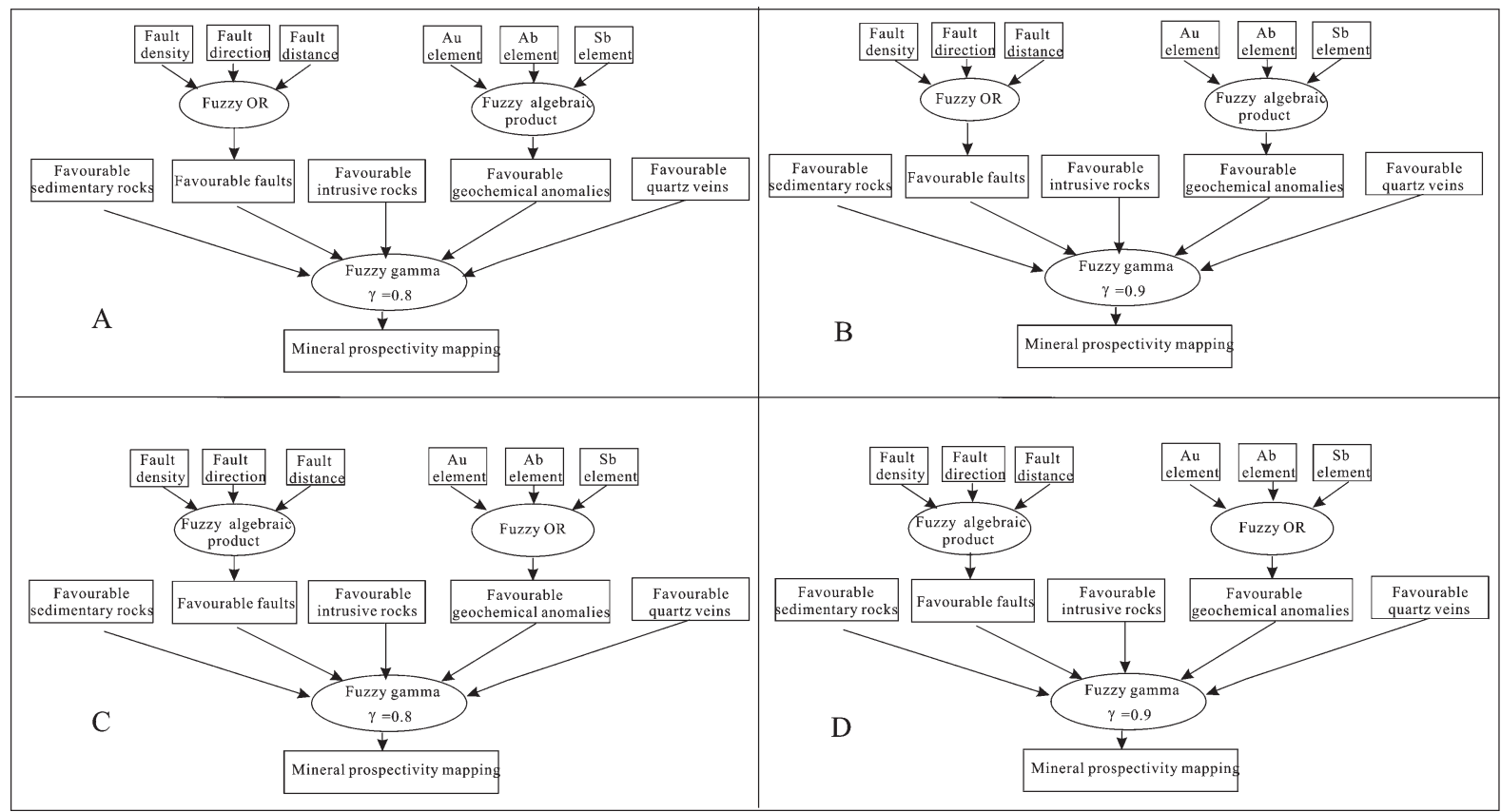

Fig. 6. The inference network map of fuzzy logic.

Table 5

Results of the four schemes

\begin{tabular}{lcc}
\hline Category & $\begin{array}{c}\text { High-favorability } \\
\text { metallogenic districts }\end{array}$ & $\begin{array}{c}\text { Number of } \\
\text { deposits covered }\end{array}$ \\
\hline A & $0.60 \%$ & 15 \\
B & $3.01 \%$ & 65 \\
C & $0.66 \%$ & 40 \\
D & $6.03 \%$ & 98 \\
\hline
\end{tabular}

\section{Discussion}

Through the application of the two models, two predictions are obtained for the study area. These two models are compared in terms of process and results.
- Process

It is evident that the weights-of-evidence model is a data-driven model. This model can quantitatively predict the relationship between each type of metallogenic information evidence and tknown deposits. Then, a metallogenic prediction is realized based on the metallogenic evidences input into the model. The entire process displays a distinct quantificational feature. However, due to the restraint imposed by the conditional independence assumption, some metallogenic evidences are excluded from the model. The posterior probability of the conditional independence is 0.0000267-0.4350819 and the posterior probability of not passing the conditional independence 


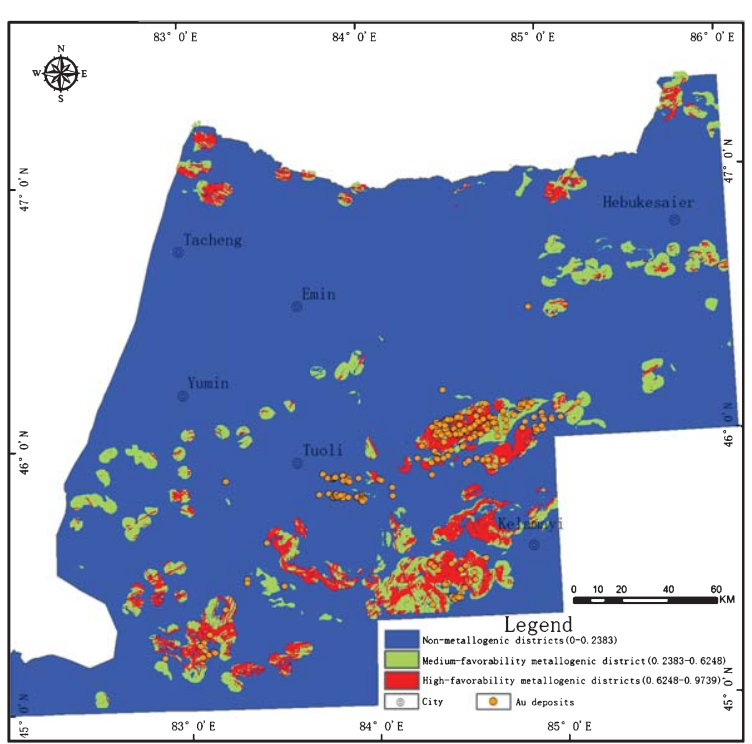

Fig. 7. Mineral prospectivity mapping with fuzzy logic method.

is $0.0000032-0.90977197$; the posterior probability of gold mineralization not passing the conditional independence test is higher than that of the gold mineralization passing this test. This agrees with results reported by researchers $[8,18]$. It is inferred that the prediction not passing the conditional independence test will affect the judgement of metallogenic prospectivity. Since the metallogenic factors are binarized by the weights-of-evidence model, some information is lost. As a result, the final prediction has a non-negligible error due to the lack of some important metallogenic evidence. The fuzzy logic model was employed on the basis of the weights-of-evidence model. Combined with a data-driven approach and expert knowledge, all considered influence factors of gold mineralization were included in the model, thus avoiding information loss due to binarization. Some small values were assigned to the factors, but experts familiar with the regional geological conditions believed that the important metallogenic factors can be assigned higher values. For example, during analysis of intrusive rock buffer distances of $6 \mathrm{~km}$ and $8 \mathrm{~km}$ using the weights-of-evidence model, the results are as follows: $\mathrm{C}=0.0638$, and $\mathrm{S}(\mathrm{c})=0.243$. However, given that 25 deposits are located within this distance, the layer was finally assigned a value of 7 according to expert opinion. Therefore, the metallogenic prediction model combined a data-driven approach with expert knowledge to produce more reliable results.

\section{- Results}

The results of mineral prospectivity mapping achieved by weights-of-evidence and fuzzy logic techniques are shown in the maps in Figs. 5 and 7. The degree of favorability of a particular location to host $\mathrm{Au}$ deposits is displayed on the legend; areas in red represent those that have been allocated high favorability values, areas in green represent those with medium favorability values, and areas in blue represent those with low favorability values. Due to a lack of some important metallogenic evidences in the weight-of-evidence model, the number of deposits and the posterior probability of gold mineralization are far lower than values obtained by the fuzzy logic model, as shown in Figs. 5 and 7, and Table 7. Therefore, the fuzzy logic model built on the basis of a datadriven approach and expert knowledge is superior to the weights-of-evidence model

Table 6

Statistical results of fuzzy logic model

\begin{tabular}{lccc}
\hline & $\begin{array}{c}\text { High-favorability } \\
\text { metallogenic districts }\end{array}$ & $\begin{array}{c}\text { Medium-favorability } \\
\text { metallogenic district }\end{array}$ & $\begin{array}{c}\text { Non-metallogenic } \\
\text { district }\end{array}$ \\
\hline Number of known deposits & 98 & 83 & 59 \\
Area covered & $6.03 \%$ & $8.06 \%$ & $85.91 \%$ \\
Highest posterior probability & 0.9739 & 0.6248 & 0.2383 \\
\hline
\end{tabular}

Table 7

Comparison of weights-of-evidence model (having passed conditional independence test) and fuzzy logic model

\begin{tabular}{lccc}
\hline & $\begin{array}{c}\text { Number of deposits included } \\
\text { in the high-favorability } \\
\text { metallogenic districts }\end{array}$ & $\begin{array}{c}\text { Highest probability of gold } \\
\text { mineralization }\end{array}$ & $\begin{array}{c}\text { Area of high-favorability } \\
\text { districts }\end{array}$ \\
\hline Weights-of-evidence model & 12 & 0.4351 & $0.17 \%$ \\
Fuzzy logic model & 98 & 0.9739 & $6.03 \%$ \\
\hline
\end{tabular}




\section{Conclusions}

In this study, weights-of-evidence and fuzzy logic methods were used to produce an Au prospectivity map of the western Junggar metallogenic belt. The results of this work lead to the following conclusions:

- Significant geological controls on gold mineralization are evident according to spatial analysis. According to the weight contrasts and studentized contrast, favorable sedimentary rock types, fault density, and fault distance were the primary factors influencing $\mathrm{Au}$ mineralization. Arsenic, $\mathrm{Sb}$, fault direction, quartz veins and intrusive rocks were secondary factors influencing Au mineralization. This suggests that sedimentary rocks, faults and $\mathrm{Au}$ geochemical anomalies are priorities for detailed mapping in future explorations.

- Conditional independence exerts great influence on the weights-of-evidence model. This study demonstrates that posterior probability would be high if the conditional independence assumption is disregarded; this will affect the accuracy of prediction. However, the conditional independence assumption is difficult to meet in reality. The conditional independence test calculates the probability that the model is not conditionally independent, and results above 95 or $99 \%$ indicate that an assumption of conditional independence should be rejected. Therefore, a concern of future study is to find better ways to satisfy the conditional independence assumption; for example, changing the method of conditional independence testing, reducing the number of weight layers or changing the number of grid units. In this way, the weights-of-evidence model can be better applied to metallogenic prediction.

- The prospectivity map obtained by the fuzzy logic model indicates a strong correlation between areas of high posterior probabilities and known Au deposits, indicating that the nine evidential layers used in this study area are valid. Based on the quantification according to weights-of-evidence and the fuzzy membership values determined by experts, the fuzzy logic method was used for mineral prospectivity mapping with high accuracy. It was determined that $25 \%$ of the deposits are outside the predicted districts, likely due to the lack of important metallogenic evidence. The prediction will be more accurate if the geophysical data can be input into the prediction model.
- The results from the weights-of-evidence and fuzzy logic methods are compared. For the study area with a large number of deposits, the datadriven approach is believed to be more suitable for mineral prospectivity mapping. However, if the data are insufficient (e.g., no geophysical data), the knowledge-driven approach (e.g., fuzzy logic method) may achieve a better prediction. A weights-of-evidence model completely relying on a data-driven approach may not be the ideal prediction model.

\section{Acknowledgments}

This work was jointly supported by the Xinjiang Uygur Autonomous Major Project (201330121-3), National Basic Research Program of China 973Program (2014CB440803) and Natural Science Foundation of China (U1129302), Young Technical Talent Cultivation Program of Xinjiang Uygur Autonomous Region (2013731014).

\section{References}

[1] A. Beuche, S. Fröjdö, P. Österholma, A. Martinkauppi and P. Edén, Fuzzy logic for acid sulfate soil mapping: Application to the southern part of the Finnish coastal areas, Geoderma 226-227 (2014), 21-30.

[2] A. Joly, A. Porwal and T.C. McCuaig, Exploration targeting for orogenic gold deposits in the Granites-Tanami Orogen: Mineral system analysis, targeting model and prospectivity analysis, Ore Geol Rev 48 (2012), 349-383.

[3] A. Najafi, M.H. Karimpour and M. Ghaderi, Application of fuzzy AHP method to IOCG prospectivity mapping: A case study in Taherabad prospecting area, eastern Iran, International Journal of Applied Earth Observation and Geoinformation 33 (2014), 142-154.

[4] A. Porwal, E.J.M. Carranza and M. Hale, Bayesian network classifiers for mineral potential mapping, Comput Geosci 32 (2006), 1-16.

[5] B.F. Han, J.J. Qinq, B. Sun and L.H. Chen, Late Paleozoic vertical growth of continental crust around the Junggar Basin, Xinjiang, China (Part I): Timing of post-collisional plutonism. Acta Petrologica Sinica (in Chinese) 22(5) (2006), 1077-1086.

[6] E.J.M. Carranza and M. Hale, Spatial association of mineral occurrences and curvilinear geological features, Mathematical Geology 34 (2002), 203-221.

[7] F.P. Agterberg and G.F. Bonham-Carter Logistic regression and weights of evidence modeling in mineral exploration, Proc. 28th Int Symp App Comput Mineral Ind (APCOM), Golden, CO, USA, 1999, pp. 483-490.

[8] F.P. Agterberg and Q.M. Cheng, Conditional independence test for weights-of-evidence modeling, Nat Resour Res 11 (2002), 249-255. 
[9] F.P. Agterberg, Automatic contouring of geological maps to detect target areas for mineral exploration, Math Geol 6(1974), 373-395.

[10] G.C. Pan and D.P. Harris Information Synthesis for Mineral Exploration, Oxford University Press, New York, NY, USA, 2000, p. 461.

[11] G.F. Bonham-Carter, F.P. Agterberg and D.F. Wright, Weights of evidence modelling: A new approach to mapping mineral potential, Statistical Applications in Earth Sciences 89(9) (1989), 171-183.

[12] G.F. Bonham-Carter Geographic Information System for Geosciences: Modelling with GIS, Pergamon Press, Oxford, 1994.

[13] J.Q. Yuan, S.Q. Zhu and Y.S. Qu, Mineral Deposits (in Chinese), Geological Press, Beijing, 1985, pp. 312-342.

[14] L.A. Zadeh, Fuzzy sets, Information and Control 8(3) (1965), 338-353.

[15] L.D. Kemp, G.F. Bonham-Carter, G.L. Raines and C.G. Looney, Arc-SDM: ArcView extension for spatial data modelling using weights of evidence, logistic regression, fuzzy logic and neural network analysis, 2001, http://www.ige. unicamp.br/sdm/

[16] L. Feltrin, Predictive modelling of prospectivity for $\mathrm{Pb}-\mathrm{Zn}$ deposits in the Lawn Hill Region, Queensland, Australia, Comput Geosci 35 (2009), 108-133.

[17] M. Abedi, S.A. Torabi and G.H. Norouzi, Application of fuzzy AHP method tointegrate geophysical data in a prospect scale, a case study: Seridune copperdeposit, Boll Geofisica Teorica Appl 54 (2013), 145-164.

[18] M.D. Lindsay, P.G. Betts and L. Ailleres, Data fusion and porphyry copper prospectivity models, southeastern Arizona, Ore Geol Rev 61 (2014), 120-140.

[19] M. Yousefi and E.J.M. Carranza, Fuzzification of continuousvalue spatial evidence for mineral prospectivity mapping, Comput Geosci 74 (2015), 97-109.

[20] N.C. Long and P. Meesad, An optimal design for type-2 fuzzy logic system using hybrid of chaos firefly algorithm and genetic algorithm and its application to sea level prediction, Journal of Intelligent \& Fuzzy Systems 27 (2014), 1335-1346.

[21] O.P. Kreuzera, A.V.M. Millerd, K.J. Petersd, C. Payned, C. Wildmand, G.A. Partingtond, E. Puccionid, M.E. McMahonc and M.A. Etheridgec, Comparing prospectivity modelling results and past exploration data: A case study of porphyry $\mathrm{Cu}$-Au mineral systems in the Macquar, Ore Geol Rev (2014), http://dx.doi.org/10.1016/j.oregeorev.2014.09.001

[22] P.A. de Palomera, F.J.A. van Ruitenbeek and E.J.M. Carranza, Prospectivity for epithermal gold-silver deposits in the Deseado Massif, Argentina, Ore Geol Rev (2014), http://dx.doi.org/10.1016/j.oregeorev.2014.12.007

[23] P. An, W.M. Moon and A.N. Rencz, Application of fuzzy theory for integration of geological, geophysical and remotely sensed data, Can J Explor Geophys 27 (1991), 1-11.

[24] Q. Cheng, Z.J. Chen and A. Khaled, Application of fuzzy weights of evidence methodin mineral resource assessment for gold in Zhenyuan District, Yunnan Province, China, Earth Sci J China Univ Geosci (In Chinese) 32 (2007), 175-184.

[25] R. Zuo and E.J.M. Carranza, Support vector machine: A tool for mapping mineral prospectivity, Comput Geosci 37(1) (2011), 1967-1975.

[26] R. Zuo, Z.J. Zhang, D.J. Zhang, E.J.M. Carranza, and H.C. Wang, Evaluation of uncertainty in mineral prospectivity mapping due to missing evidence: A case study with skarn-type Fe deposits in Southwestern Fujian Province, China, Ore Geol Rev (2014), http://dx.doi.org/10.1016/j.oregeorev.2014.09.024

[27] W.M. Brown, T.D. Gedeon, D. Groves and R.G. Barnes, Artificial neural networks: A new method for mineral prospectivity mapping, Aust J Earth Sci 47 (2000), 757-770.

[28] Y. Chen, Mineral potential mapping with a restricted Boltzmann machine, Ore Geol Rev (2014), http://dx. doi.org/10.1016/j.oregeorev.2014.08.012

[29] Y.E. Molan and P. Behnia, Prospectivity mapping of $\mathrm{Pb}-\mathrm{Zn}$ SEDEX mineralization using remote-sensing data in the Behabad area, Central Iran, Int J Remote Sens 34(4) (2013), 1164-1179.

[30] Z.H. Wang, Y. Zhang and K.Q. Wang, Metallogenic rule and prospecting orientation of gold depositsin western Junggar, Xinjiang, Gold (in Chinese) 29(6) (2008), 13-17.

[31] Z.H. Zhao, Z.H. Bai, X.L. Xiao and H.J. Mei, The Mineralization of the Rich Alkali Igneous Rocks in Northern China, Xinjiang (in Chinese), Geological Press, Beijing, 2006, pp. $1-302$. 